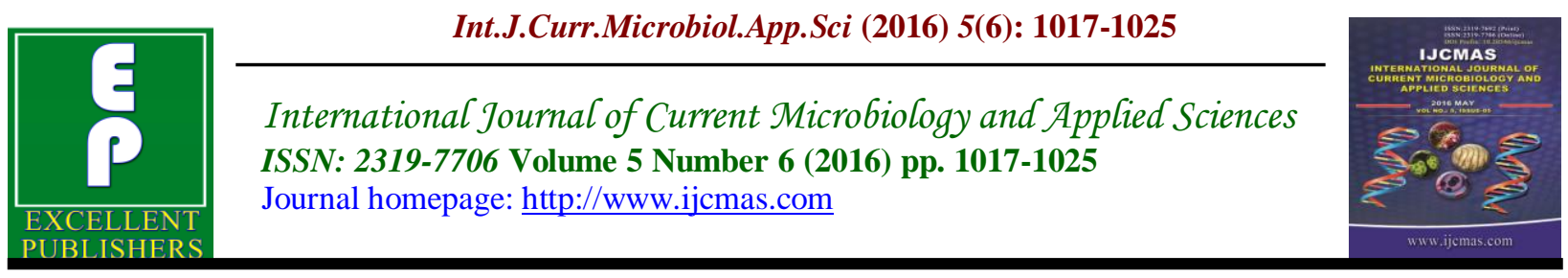

Original Research Article

http://dx.doi.org/10.20546/ijcmas.2016.506.108

\title{
Isolation and Identification of food borne pathogens from Spoiled food samples
}

\author{
V.B. Hemalata and D.B.M. Virupakshaiah* \\ Department of Biotechnology Basaveshwar Engineering College, Bagalkot, India \\ *Corresponding author
}

\begin{tabular}{|c|c|}
\hline & A B S T R A C T \\
\hline $\begin{array}{l}\text { K e y w o r d s } \\
\text { Cephalosporins, } \\
\text { Fluoroquinolones, } \\
\text { Beta-Lactams, } \\
\text { Aminoglycosides, } \\
\text { Pseudomonas. }\end{array}$ & \multirow{3}{*}{$\begin{array}{l}\text { Studies were performed to identify various pathogenic bacteria from different } \\
\text { sources like; spoiled fruits, vegetables, Dairy products, Bakery products, Poultry } \\
\text { products and Spoiled rice were selected from local market of Bagalkot district, } \\
\text { Karanataka, India. Collected samples were examined in specific media like } \\
\text { Mannitol Salt agar, MacConkey agar and Cetrimide agar. Samples were confirmed } \\
\text { by both phenotypic and genotypic characteristics. The pathogenic bacterial isolates } \\
\text { such as Pseudomonas spp [23.66\%], Staphylococcus aureus [22.76\%], Salmonella } \\
\text { spp [21.87\%], E.coli [22.32\%] and Klebsiella spp [8.92\%] were present in large } \\
\text { amount. The percentage of multidrug-resistant (MDR) isolates was high in } \\
\text { numbers and the most prevalent resistant pattern included four different classes of } \\
\text { antibiotics; Cephalosporins, Fluoroquinolones, Beta-Lactams and } \\
\text { Aminoglycosides. }\end{array}$} \\
\hline Article Info & \\
\hline $\begin{array}{l}\text { Accepted: } \\
\text { 25 May } 2016 \\
\text { Available Online: } \\
\text { 10 June } 2016\end{array}$ & \\
\hline
\end{tabular}

\section{Introduction}

Microorganisms are the primary cause of food spoilage and food borne illness. Food borne diseases are globally important, as they result in considerable morbidity, mortality, and economic costs. Many different sources like bacteria, viruses, parasites, chemicals, and prisons, may be transmitted to humans by contaminated food. Outbreaks and sporadic cases of food borne disease are regular occurrences in all countries of the world (Kirk et al., 2015). However, the statistical data of food borne illness is increased due to the unrecognized or unreported outbreaks particularly in the developing countries (Han et al., 2014).
There has been a continuous increase in several food borne diseases caused by bacterial pathogens such as Salmonella, Campylobacter, E.coli, Listeria, S.auerus, Klebsiella and Pseudomonas. These pathogens come into contact with foods during harvest or slaughtering, processing, storage and packaging. Environmental challenges have caused food-borne bacterial pathogens to evolve and the susceptibility of human population to infections (Chibeu, 2013), Generally, food borne diseases are associated with acute, mild and self-limiting gastroenteritis with symptoms such as nausea, vomiting and diarrhea as a consequence of consumption of microbial contaminated food and number of chronic sequences may result from food borne 
infections involving diseases that affect the cardiovascular, musculoskeletal, and respiratory and immune systems (Han et al., 2014).

Most bacteria and fungi that arrive on the developing crop plant like fruits and vegetables provide a natural biological barrier to infestation by the subset of microorganisms responsible for crop damage (Mohamed et al., 2012) when the soil is fertilized by human sewage or if crops are irrigated with sewage water and also during harvesting and post harvest handling, or during storage, distribution or also get contaminated by soil, air and water (Mohamed et al., 2012) Moreover, food products are at risk of contamination with mishandling during processing and preparations where there are favorable conditions for pathogens (Kakarla et al., 2015) and also responsible for causing spoilage to the edible portion of the crop. In most of the cases food like dairy product, fish and poultry product get contaminated while handling of the product, harvesting and processing equipment and transport (Saranraj et al., 2012) Food products may become contaminated at different stages along the food chain, from growth or production until the final consumption (Sillankorva et al., 2012).

In most of the cases microorganism like E.coli in meat product, drinking water and dairy product; Salmonella, S.auerus in meat, eggs, on vegetables and poultry; Listeria in dairy product and shellfish; Pseudomonas on fruit, dairy product, poultry and in drinking water.

The prevalence of Multi Drug Resistant (MDR) foodborne pathogens is increased by consumption of contaminated food because they are responsible for more serious disease than susceptible bacteria (Gohary et al., 2015). Antibiotic is ineffective due to bacterial resistance, and therefore the infection persists and the illness progresses (Brunelle et al., 2013). The main objective of this study is Identification of pathogens from different food source like Fruits, Vegetables, Dairy products, Bakery products, spoiled rice and Poultry product collected from the bagalkot district.

\section{Materials and Methods}

\section{Sample collection}

A Total of 79 different food sources are collected from local market in and around Bagalkot district, Karnataka, India. All the samples were wrapped separately in sterile polyethylene bags and plastic bags and transported to the laboratory for microbial analysis.

\section{Isolation of food borne pathogens}

The samples are rinsed thoroughly with distilled water and used for isolation of bacteria on specific media Mannitol Salt agar, MacConkey agar and Cetrimide agar at $37^{\circ} \mathrm{C}$ for 24 hours.

\section{Phenotypic characterization of isolates}

Bacteria are identified by cultural characteristics such as abundance of growth, color change in media and morphological characteristics like form, size, margin and elevation are studied on culture plates. Identifying an isolates by Gram's reactionGram's staining, Motility determinationHanging drop method and Soft agar stabbing (Tube Method), Catalase, Oxidase, Nitrate Reduction, IMVIC test, Carbohydrate Utilization, Urease production, Gelatin Hydrolysis, Coagulase Test and DNase Test were performed for the confirmation of the Bacterial isolates according to the bergey's manual. 


\section{Antibiotic Susceptibility Test}

Antimicrobial Susceptibility testing was performed on Mueller- Hinton Agar by Standard disk diffusion method as recommended by the CLSI-2010. The twelve different antibiotic discs were used like, Cefotaxime (cephotaxime) (30 mcg), Nitrofurantoion(300mcg), Co-trimoxazole (Sulpha/trimethoprim) (25mcg), Meropenem (10mcg), Imipenem (10mcg), Amikacin (30mcg), Gentamicin (10mcg), Tetracycline (30mcg), Amoxyclav (30mcg), Ertapenem (10mcg), Ceftriaxone (10mcg) and Cefazolin (30mcg). Mueller-Hinton plates were incubated at $35{ }^{\circ} \mathrm{C}$ for 16 to 18 hours after inoculation with organisms and zones of inhibition were measured in Millimetre (mm).

\section{Determination of Minimal inhibitory concentration (MIC)}

Determination of resistant isolates was used for MIC by agar dilution method. MIC was done by using Meropenem, Amikacin, Amoxyclav and Gentamicin antibiotic with different concentration.

\section{Results and Discussion}

\section{Sample collection}

Samples are collected from local market in and around Bagalkot district, Karanataka, India, in sterile plastic bags and microbial analysis are done for those samples as shown in table 1 .

\section{Isolation of food borne pathogens}

Pathogens are isolated by using specific media like 1)Mannitol Salt agar was used for the identification of food borne Staphylococcus aureus which ferment Mannitol, whereas Staphylococcus epidermidis is a non fermenting Mannitol.
2) MacConkey Agar was used for the identification of food borne Salmonella which is non-Lactose fermenter and Lactose fermenting organism like E.coli and Klebsiella and 3) Cetrimide agar was used for the identification of food borne Pseudomonas which is selective media for the bacterium. By using 3different media totally different organism were identified based on color change in media and colony morphology as shown in table 2. Among the various isolated pathogens Pseudomonas is predominant so, we are focusing on Pseudomonas.

\section{Phenotypic characterization of isolates}

Based on color change in media, morphological characteristics and biochemical characteristics were studied and confirmed. Out of 79 samples, 224 total isolates are found in present work, in that 53 Pseudomonas isolates [23.66\%], 51 Staphylococcus aureus[22.76\%], 49 Salmonella[21.87\%], 50 E.coli [22.32\%] and 20 Klebsiella[8.92\%]. Pseudomonas is a Gram negative, rod shaped, Motile (Unipolar), Non spore forming, Catalase positive, Oxidative positive, Nitrate Reduction positive and Non-fermentative. Staphylococcus aureus is a Gram positive, cocci, Non-Motile, Non-Spore forming, Catalase positive, Nitrate Reduction positive, Methy-red positive, Vogesproskauer positive, DNase positive and Fermentative. Salmonella is a Gram negative, rod shaped bacteria, Non spore forming, predominately motile, Peritrichous flagella, Catalase positive, Nitrate Reduction positive and Fermentative. E.coli is a Gram negative, Non spore forming, rod shaped bacteria, Motile, Flagellated, Catalase positive, Nitrate Reduction positive and Fermentative. Klebsiella is a genus of non motile, Non spore forming, Gram negative, oxidase negative, rod shaped bacteria with prominent polysaccharide based capsule. 


\section{Antibiotic Susceptibility Test}

In this test many of the pathogens shows resistance towards four different classes of antibiotic(as shown in fig 2) as recommended by the CLSI-2010(Clinical Laboratory Standard Institute) and Quality Assurance Guidelines(QAG) of WHO (World Health Organization).

\section{Determination of Minimal Inhibitory Concentration (MIC)}

MIC was carried out for all four antibiotics. Among total 53 Pseudomonas isolates, 21 isolates showed multidrug resistance. 20 resistant isolates were selected for MIC; the obtained results are shown in table 4.

The incidence of food borne illnesses is found to be increased day to day life. The presence of microorganisms is more in numbers of viable bacteria, an indicator of the expected shelf life of the food sources, increases the likelihood of spoilage, as well as the possibility of produce-associated outbreaks (Allydice-Francis et al., 2012).

The microorganisms present in Fruits, Vegetables, Dairy products, Spoiled rice, Poultry products and Bakery products are a direct reflection of the sanitary quality of the cultivation water, harvesting, transportation, storage, and processing of the product (Eni et al., 2010).

At the present 79 samples were examined for bacterial growth in specific media and the bacterial isolates were identified and confirmed by Biochemical tests include 53 Pseudomonas isolates [23.66\%], 51 Staphylococcus aureus [22.76\%], 49 Salmonella [21.87\%], 50 E.coli [22.32\%] and 20 Klebsiella [8.92\%].

Prevalence of common food borne pathogens (Salmonella, Staphylococcus and E. Coli) in chicken meat(Glenn et al.,2015)
(Ruban et al., 2012).Prevalence of S. aureus in many food products including raw retail meat indicating that consumers are at potential risk of $S$. aureus colonization and subsequent infection (Kadariya et al., 2014). Consumption of raw or insufficiently heat treated fish, which may be contaminated with bacteria from water environment (Vibrio spp., C. botulinum) or terrestrial sources (C. perfringens, Salmonella spp., Shigella spp., Staphylococcus spp., $V$. cholerae), or fish products recontaminated after heat processing (Novotny et al.2004). Salmonella, Escherichia coli, and Staphylococcus aureus are the main predominant species in most food poisoning cases associated with contaminated raw or undercooked poultry and red meat (Gwida et al., 2015) (Dan et al., 2015). Salmonella spp and Escherichia coli are the two most important food-borne pathogens of public health interest incriminated in poultry meat worldwide (Adeyanju et al., 2014).

Pseudomonas spp. was one of the most frequently identified agents associated with waterborne outbreaks of dermatitis (rash or folliculitis), as well as conjunctivitis, otitis externa and other symptoms, in recreational water in the United States of America (Uğur et al.,2012)and shows resistance of $P$. aeruginosa to commonly used therapeutic agents has increased in recent years.

Multidrug-resistant (MDR) can be defined as resistance to at least four classes of antibiotics used during treatment of these infections: third-generation Cephalosporins, Fluoroquinolones, Aminoglycosides, and Carbapenems (Gómez et al., 2012). In present work Pseudomonas, Staphylococcus aureus, Salmonella, E.coli and Klebsiella shows resistance for four classes of antibiotics (Cephalosporins, Fluoroquinolones, Beta-Lactams and Aminoglycosides). 
Table.1 Number of samples used for isolation

\begin{tabular}{|c|c|l|c|c|}
\hline Sl .no & Source & \multicolumn{1}{|c|}{ Samples } & $\begin{array}{c}\text { Total number of } \\
\text { samples }\end{array}$ & $\begin{array}{c}\text { Total number of } \\
\text { isolates }\end{array}$ \\
\hline 1 & Fruits & $\begin{array}{l}\text { Apple(BG) I, Apple (S) II, Mosambi, Orange, Fig, } \\
\text { Strawberry, Banana, Small banana, Chickoo, Passion } \\
\text { fruit, Grapes (Black), Custard apple, Lemon, Musk } \\
\text { melon, Javari banana and Water mellon. }\end{array}$ & 16 & 43 \\
\hline 2 & Vegetables & $\begin{array}{l}\text { Tomato (bg), Tomato (S), Bitter guard, Green chilly, } \\
\text { Capsicum (B), Capsicum (S), Potato, Onion, Beans, } \\
\text { Carrot, Ladies finger, Flat bean(surti papdililva), Methi } \\
\text { leave (fenugreek greens), Coriander leaves, Amla, Ridge } \\
\text { guard, Cauliflower, Gulgaya /meka, Spinach, Peace, } \\
\text { Cluster bean, Pundi, Drum stick and Brinjal }\end{array}$ & 24 & 70 \\
\hline 3 & Dairy products & $\begin{array}{l}\text { Cow milk, Raw milk, Sambhrudi, Peda[nandini], Butter } \\
\text { milk, Curd, Kunda[Belgaum], Cheese slice, Cheese } \\
\text { cube, Shrikhand, Paneer and Dairy sewage. }\end{array}$ & 13 & \\
\hline 4 & $\begin{array}{c}\text { Bakery } \\
\text { products }\end{array}$ & $\begin{array}{l}\text { Cake, Bread, Karadantu, Soan papdi, Ladagi ladu, } \\
\text { Moothi chur, Gulab Jamun, Mysurpak, Badam puri, } \\
\text { Besan laddu, Peda and Bella Jellaby. }\end{array}$ & 12 & \\
\hline 5 & $\begin{array}{c}\text { Poultry } \\
\text { products }\end{array}$ & $\begin{array}{l}\text { Chicken, Mutton, Snake fish, Fish[M], Egg[Y] and Egg } \\
\text { [Y+W] }\end{array}$ & 12 & 38 \\
\hline 6 & Spoiled rice & Sample 1 \& Sample 2 & 02 & 22 \\
\hline & & & $\begin{array}{l}\text { Total No of } \\
\text { samples=79 }\end{array}$ & $\begin{array}{c}\text { Total No of } \\
\text { isolates=224 }\end{array}$ \\
\hline
\end{tabular}

Table.2 Number of isolates in food samples

\begin{tabular}{|c|c|c|c|c|c|c|c|c|}
\hline $\begin{array}{l}\mathrm{S} 1 \\
\text { no }\end{array}$ & Sample & $\begin{array}{c}\text { Total } \\
\text { number of } \\
\text { samples }\end{array}$ & $\begin{array}{c}\text { Total } \\
\text { number of } \\
\text { isolates }\end{array}$ & $\begin{array}{c}\text { Total } \\
\text { number of } \\
\text { Pseudomona } \\
s \text { isolates }\end{array}$ & $\begin{array}{c}\text { Total } \\
\text { number of } \\
\text { S.auerus } \\
\text { isolates }\end{array}$ & $\begin{array}{c}\text { Total } \\
\text { number of } \\
\text { Salmonella } \\
\text { isolates }\end{array}$ & $\begin{array}{c}\text { Total } \\
\text { number of } \\
\text { E.coli } \\
\text { isolates }\end{array}$ & $\begin{array}{c}\text { Total } \\
\text { number of } \\
\text { Klebsiella } \\
\text { isolates }\end{array}$ \\
\hline 1 & Fruits & 16 & 43 & 06 & 11 & 12 & 09 & 05 \\
\hline 2 & Vegetables & 24 & 70 & 21 & 18 & 14 & 14 & 03 \\
\hline 3 & $\begin{array}{c}\text { Dairy } \\
\text { products }\end{array}$ & 13 & 45 & 12 & 06 & 09 & 11 & 08 \\
\hline 4 & $\begin{array}{l}\text { Bakery } \\
\text { products }\end{array}$ & 12 & 38 & 03 & 12 & 10 & 09 & 04 \\
\hline 5 & $\begin{array}{l}\text { Poultry } \\
\text { products }\end{array}$ & 12 & 22 & 10 & 04 & 03 & 05 & 00 \\
\hline \multirow[t]{2}{*}{6} & Spoiled rice & 02 & 06 & 01 & 00 & 01 & 02 & 00 \\
\hline & & $\begin{array}{c}\text { Total No } \\
\text { of } \\
\text { samples }=7 \\
9\end{array}$ & $\begin{array}{c}\text { Total No } \\
\text { of } \\
\text { isolates= } \\
224\end{array}$ & $\begin{array}{c}\text { Total no of } \\
\text { Pseudomona } \\
s=53 \\
{[23.66 \%]}\end{array}$ & $\begin{array}{c}\text { Total } \\
\text { number of } \\
\text { S.auerus }=51 \\
{[22.76 \%]}\end{array}$ & $\begin{array}{c}\text { Total } \\
\text { number of } \\
\text { Salmonella= } \\
49 \\
{[21.87 \%]}\end{array}$ & $\begin{array}{c}\text { Total } \\
\text { number of } \\
\text { E.coli }=50 \\
{[22.32 \%]}\end{array}$ & $\begin{array}{c}\text { Total } \\
\text { number of } \\
\text { Klebsiella } \\
=20 \\
{[8.92 \%]}\end{array}$ \\
\hline
\end{tabular}


Table.3 Percentage of multi drug resistant bacteria as shown in table 3

\begin{tabular}{|c|c|c|c|c|c|c|c|c|c|c|c|c|}
\hline \multirow{2}{*}{ Isolates } & \multicolumn{10}{|c|}{ Antibiotics used for the Antibiotic Susceptibility Test } \\
\cline { 2 - 16 } & $\begin{array}{l}\text { CTX } \\
\%\end{array}$ & $\begin{array}{l}\text { NIT } \\
\%\end{array}$ & $\begin{array}{l}\text { COT } \\
\%\end{array}$ & $\begin{array}{l}\text { MRP } \\
\%\end{array}$ & $\begin{array}{l}\text { IPM } \\
\%\end{array}$ & $\begin{array}{l}\text { AK } \\
\%\end{array}$ & $\begin{array}{l}\text { AMC } \\
\%\end{array}$ & $\begin{array}{l}\text { GEN } \\
\%\end{array}$ & $\begin{array}{l}\text { TTP } \\
\%\end{array}$ & $\begin{array}{l}\text { CTR } \\
\%\end{array}$ \\
\hline Pseudomonas & 45 & 43 & 65 & 77 & 52 & 65 & 97 & 84 & 46 & 54 & 46 & 40 \\
\hline S.auerus & 77 & 45 & 46 & 52 & 43 & 97 & 54 & 65 & 84 & 65 & 46 & 54 \\
\hline Salmonella & 84 & 54 & 43 & 65 & 45 & 52 & 77 & 46 & 97 & 46 & 65 & 46 \\
\hline E.coli & 45 & 46 & 65 & 84 & 54 & 43 & 46 & 52 & 65 & 97 & 40 & 77 \\
\hline Klebsiella & 65 & 43 & 40 & 46 & 97 & 54 & 84 & 77 & 46 & 52 & 45 & 65 \\
\hline
\end{tabular}

Cefotaxime (cephotaxime)30mcg - [CTX], Nitrofurantoion 300mcg -[NIT], Co-trimoxazole

(Sulpha/trimethoprim)25mcg -[COT], Meropenem 10mcg - [MRP], Imipenem 10mcg -[IPM], Amikacin 30mcg -

[AK], Gentamicin 10mcg -[GEN], Tetracycline 30mcg -[TE], Amoxyclav 30mcg -[AMC], Ertapenem 10mcg -

[ETP], Ceftriaxone 10mcg - [CTR], Cefazolin 30mcg - [CZ].

Table.4 MIC of the resistant bacteria

\begin{tabular}{|c|c|c|c|c|c|c|c|c|c|}
\hline Sample & \multicolumn{4}{|c|}{ Antibiotics } & Sample & \multicolumn{4}{c|}{ Antibiotics } \\
\hline & $\begin{array}{c}\text { Merope } \\
\text { nem }\end{array}$ & $\begin{array}{c}\text { Amikac } \\
\text { in }\end{array}$ & $\begin{array}{c}\text { Amoxycl } \\
\text { av }\end{array}$ & $\begin{array}{c}\text { Gentami } \\
\text { cin }\end{array}$ & & $\begin{array}{c}\text { Meropen } \\
\text { em }\end{array}$ & $\begin{array}{c}\text { Amikaci } \\
\mathrm{n}\end{array}$ & $\begin{array}{c}\text { Amoxycla } \\
\text { v }\end{array}$ & $\begin{array}{c}\text { Gentam } \\
\text { icin }\end{array}$ \\
\hline R1 & $32 \mu \mathrm{g}$ & $8 \mu \mathrm{g}$ & $1024 \mu \mathrm{g}$ & $16 \mu \mathrm{g}$ & $\mathrm{R} 11$ & $128 \mu \mathrm{g}$ & $64 \mu \mathrm{g}$ & $1024 \mu \mathrm{g}$ & $128 \mu \mathrm{g}$ \\
\hline R2 & $16 \mu \mathrm{g}$ & $8 \mu \mathrm{g}$ & $256 \mu \mathrm{g}$ & $8 \mu \mathrm{g}$ & $\mathrm{R} 12$ & $8 \mu \mathrm{g}$ & $8 \mu \mathrm{g}$ & $512 \mu \mathrm{g}$ & $8 \mu \mathrm{g}$ \\
\hline R3 & $16 \mu \mathrm{g}$ & $8 \mu \mathrm{g}$ & $512 \mu \mathrm{g}$ & $8 \mu \mathrm{g}$ & $\mathrm{R} 13$ & $64 \mu \mathrm{g}$ & $8 \mu \mathrm{g}$ & $512 \mu \mathrm{g}$ & $8 \mu \mathrm{g}$ \\
\hline R4 & $16 \mu \mathrm{g}$ & $8 \mu \mathrm{g}$ & $512 \mu \mathrm{g}$ & $8 \mu \mathrm{g}$ & $\mathrm{R} 14$ & $64 \mu \mathrm{g}$ & $8 \mu \mathrm{g}$ & $256 \mu \mathrm{g}$ & $8 \mu \mathrm{g}$ \\
\hline R5 & $32 \mu \mathrm{g}$ & $8 \mu \mathrm{g}$ & $512 \mu \mathrm{g}$ & $8 \mu \mathrm{g}$ & $\mathrm{R} 15$ & $64 \mu \mathrm{g}$ & $8 \mu \mathrm{g}$ & $512 \mu \mathrm{g}$ & $8 \mu \mathrm{g}$ \\
\hline R6 & $8 \mu \mathrm{g}$ & $8 \mu \mathrm{g}$ & $512 \mu \mathrm{g}$ & $8 \mu \mathrm{g}$ & $\mathrm{R} 16$ & $8 \mu \mathrm{g}$ & $8 \mu \mathrm{g}$ & $512 \mu \mathrm{g}$ & $8 \mu \mathrm{g}$ \\
\hline R7 & $8 \mu \mathrm{g}$ & $8 \mu \mathrm{g}$ & $64 \mu \mathrm{g}$ & $8 \mu \mathrm{g}$ & $\mathrm{R} 17$ & $64 \mu \mathrm{g}$ & $8 \mu \mathrm{g}$ & $512 \mu \mathrm{g}$ & $8 \mu \mathrm{g}$ \\
\hline R8 & $64 \mu \mathrm{g}$ & $8 \mu \mathrm{g}$ & $512 \mu \mathrm{g}$ & $8 \mu \mathrm{g}$ & $\mathrm{R} 18$ & $32 \mu \mathrm{g}$ & $8 \mu \mathrm{g}$ & $512 \mu \mathrm{g}$ & $8 \mu \mathrm{g}$ \\
\hline R9 & $8 \mu \mathrm{g}$ & $8 \mu \mathrm{g}$ & $512 \mu \mathrm{g}$ & $8 \mu \mathrm{g}$ & $\mathrm{R} 19$ & $32 \mu \mathrm{g}$ & $8 \mu \mathrm{g}$ & $256 \mu \mathrm{g}$ & $8 \mu \mathrm{g}$ \\
\hline R10 & $8 \mu \mathrm{g}$ & $8 \mu \mathrm{g}$ & $512 \mu \mathrm{g}$ & $8 \mu \mathrm{g}$ & $\mathrm{R} 20$ & $64 \mu \mathrm{g}$ & $8 \mu \mathrm{g}$ & $512 \mu \mathrm{g}$ & $8 \mu \mathrm{g}$ \\
\hline
\end{tabular}

Fig.1 Growth of bacterial colonies on specific media

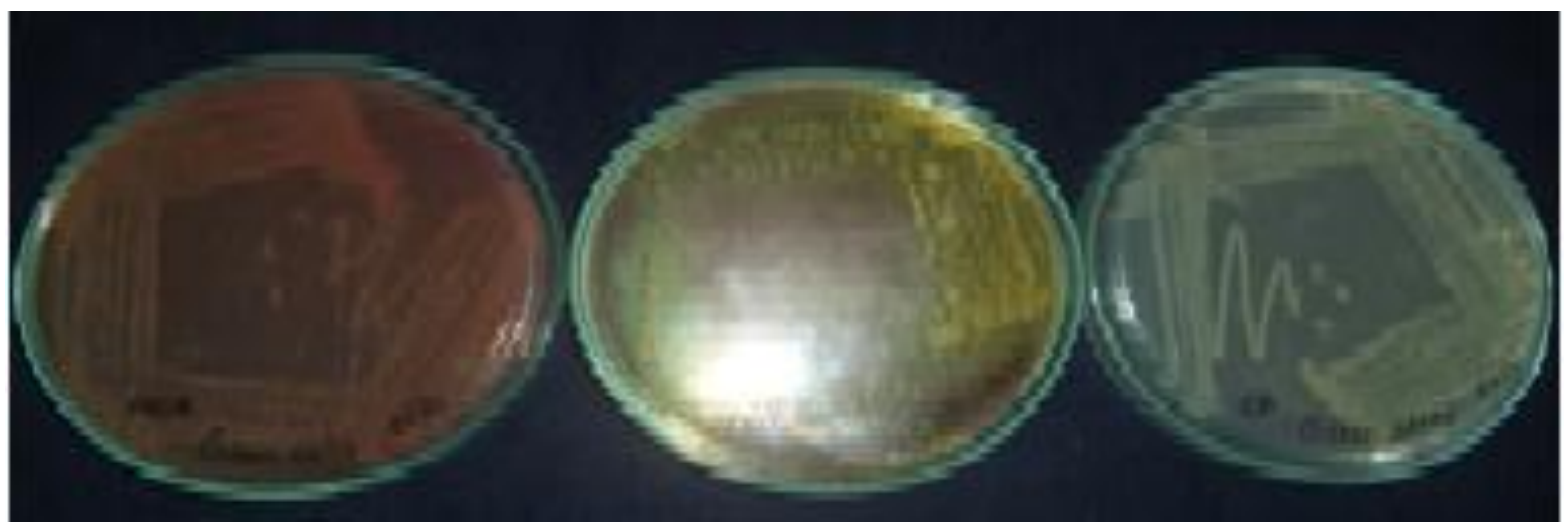


Fig.2 Pathogens showing resistance for Multi Drug

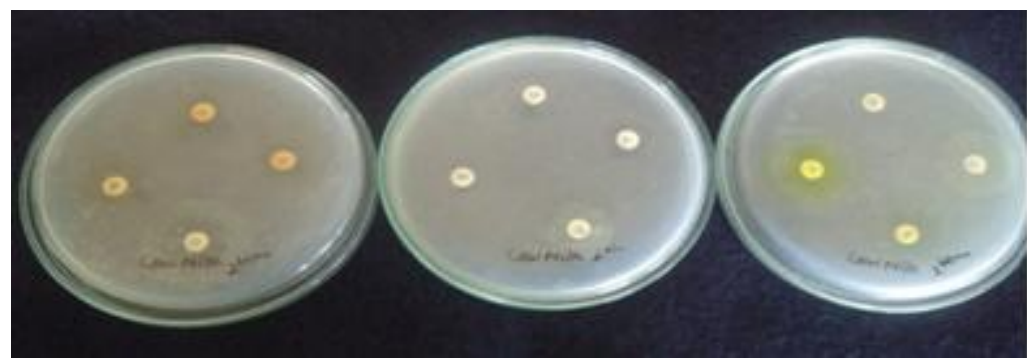

Resistance of food borne pathogens to antibiotics is a serious problem and the development of resistance-free antibacterial agents is necessary to treat bacterial infections effectively. In present work 20 multidrug resistant bacterial isolates were selected for Minimum Inhibitory Concentration (MIC) and results were as shown in table 3. Few bacteria show resistant at low concentration and few shows for higher concentration. These organisms have frequently been associated with food products and linked to a number of human illness cases from various products such as meat, milk and milk products, vegetables, poultry, and fish due to microorganisms resistant to multiple antimicrobial agents showed great antibacterial effectiveness on four important food borne pathogens.

In conclusion, prevalence of food borne illness and food borne pathogens were increasing day to day life. Due to food products get contaminated while handling, harvesting and processing in equipments and transportation. Food products may become contaminated at different stages along the food chain, from growth or production until reach to the consumers. Keeping all this in our mind we made a little effort to adders this serious concerned. In present work we have isolated over 79 food samples like spoiled Fruits, Vegetables, Dairy products, Bakery products, Poultry products and Spoiled rice were selected to isolate food spoiling bacteria. Among the isolates many of them shows resistance or had reduced susceptibilities to multiple antimicrobial agents. And also we found most of the isolates belong to Pseudomonas spp. It has shows high multi drug resistance rate compared to other bacterial isolates.

\section{References}

Martyn D. Kirk, Sara M. Pires, Robert E. Black, Marisa Caipo, John A. Crump,Brecht Devleesschauwer, Dörte Döpfer, Aamir Fazil, Christa L. Fischer-Walker, Tine Hald, Aron J. Hall, Karen H. Keddy, Robin J. Lake, Claudio F. Lanata, Paul,R. Torgerson, Arie H. Havelaar, Frederick J. Angulo. "World Health Organization Estimates of the Global and Regional Disease Burden of 22 Foodborne Bacterial, Protozoal, and Viral Diseases, 2010: A Data Synthesis". PLOS Medicine. 2015; 12(12).

Tan Loh Teng-Hern, Chan Kok-Gan and Lee Learn Han. "Application of Bacteriophage in Biocontrol of Major Foodborne Bacterial Pathogens". Journal of Molecular Biology and Molecular Imaging. 2014; 1(1): 9.

Jody L. Andersen, Gui-Xin He, Prathusha Kakarla, Ranjana KC, Sanath Kumar, Wazir Singh Lakra, Mun Mun Mukherjee, Indrika Ranaweera, Ugina Shrestha, Thuy Tran and Manuel F. Varela. "Multidrug Efflux Pumps from Enterobacteriaceae, Vibrio cholerae 
and Staphylococcus aureus Bacterial Food Pathogens". Int. J. Environ. Res. Public Health. 2015; 12, 1487-1547.

Mohamed Mahroop Raja, M., Raja, A., Mohamed Hajee, S. and Sheik Mohamed, A. "Screening of bacterial compost from spoiled vegetables and fruits and their physiochemical characterization". International Food Research Journal. 2012; 19 (3): 11931198.

Chibeu, A., Bacteriophages in food safety.,Formatex, 2013; 1041 1052.]

Sanna M. Sillankorva, Hugo Oliveira, and Joana Azeredo. "Bacteriophages and Their Role in Food Safety". International Journal of Microbiology. 2012; 1-13.

P. Saranraj, D. Stella and D. Reetha., "Microbial Spoilage Of Vegetables And Its Control measures: A Review". International Journal of Natural Produ ct Science 2012; 2(2): 1-12.

Mayada Gwida and Adel El-Gohary, "Prevalence and Characterization of Antibiotic Resistance Food Borne Pathogens Isolated from Locally Produced Chicken Raw Meat and their Handlers".Journal of Dairy, Veterinary and Animal Research. 2015; 3(1); 1-7.

Brian W Brunelle, Shawn MD Bearson and Bradley L Bearson. "Tetracycline accelerates the temporally-regulated invasion response in specific isolates of multidrug-resistant Salmonella enterica serovar Typhimurium". BioMed Central. Microbiology 2013, 13:202.

Kashina Allydice-Francis and Paul D. Brown. "Diversity of Antimicrobial Resistance and Virulence Determinants in Pseudomonas aeruginosa Associated with Fresh Vegetables". International Journal of Microbiology.2012; 1-7.
Angela Obaigeli Eni, Ibukunoluwa Adesuwa Oluwawemitan and Oranusi U. Solomon. "Microbial quality of fruits and vegetables sold in Sango Ota, Nigeria". African Journal of Food Science. 2010; 4(5).

LaShanda M. Glenn, Rebecca L. Lindsey, Jason P. Folster, Jean M. Whichard, Gary Pecic, Patrick Boerlin, Mathew W. Gilmour, Patrick F. McDermott, Heather Harbottle, Paula J. FedorkaCray, and Jonathan G. Frye. "Antimicrobial resistance genes in multi-drug resistant Salmonella enterica serovars isolated most frequently from animals, retail meat, and humans in the U.S. and Canada". Microb Drug Resist. 2013; 19(3): 175-184.

Wilfred Ruban, S., Nithin Prabhu, K. and Naveen Kumar, G.S. "Prevalence of food borne pathogens in market samples of chicken meat in Bangalore". International Food Research Journal. 2012; 19(4): 17631765.

Jhalka Kadariya, Tara C. Smith, and Dipendra Thapaliya. "Staphylococcus aureus and Staphylococcal FoodBorne Disease: An Ongoing Challenge in Public Health". BioMed Research International. 2014; 9, 1-9.

L.Novotny, L.Dvorska, A.Lorencova, V.Beran, I.Pavlik. "Fish: a potential source of bacterial pathogens for human beings". Ministry of Agriculture of the Czech Republic. 2004. 49 (9): 343-358.

Sorin Daniel Dan, Alexandra Tăbăran, Liora Mihaiu, Marian Mihaiu. "Antibiotic susceptibility and prevalence of foodborne pathogens in poultry meat in Romania". J Infect Dev Ctries 2015; 9(1):035-041.

Gladys Taiwo Adeyanju and Olayinka Ishola. "Salmonella and Escherichia 
coli contamination of poultry meat from a processing plant and retail markets in Ibadan, Oyo State, Nigeria". Adeyanju and Ishola SpringerPlus 2014, 3:139.

Aysel Uğur, Özgür Ceylan and Belma Aslım. "Characterization of Pseudomonas spp. from seawater of the southwest coast of Turkey". J.
Biol. Environ. Sci., 2012, 6(16), 1523.

Marilyn Porras-Gómez, José Vega-Baudrit, Santiago Núñez-Corrales. "Overview of Multidrug-Resistant Pseudomonas aeruginosa and Novel Therapeutic Approaches". Journal of Biomaterials and Nanobiotechnology, 2012, 3, 519527.

\section{How to cite this article:}

Hemalata, V.B., and Virupakshaiah, D.B.M.2016. Isolation and Identification of food borne pathogens from Spoiled food samples. Int.J.Curr.Microbiol.App.Sci. 5(6): 1017-1025. doi: http://dx.doi.org/10.20546/ijcmas.2016.506.108 